\title{
地震時におけるバラスト軌道の道床横抵抗力 特性
}

\author{
中村貴久 1 ・桃谷尚嗣 2 ・早野公敏 3 ・小川隆太 4 \\ 1正会員 (公財)鉄道総合技術研究所 軌道技術研究部 （†185-8540 東京都国分寺市光町2-8-38） \\ E-mail : takahisa.nakamura.19@ rtri.or.jp \\ 2 正会員 博士 (工） (公財)鉄道総合技術研究所 軌道技術研究部（广185-8540 東京都国分寺市光町 2-8-38） \\ ${ }^{3}$ 正会員 博士（工） 横浜国立大学大学院都市イノベーション研究院（テ240-8501 神奈川県 \\ 横浜市保土ヶ谷区常磐台79-5) \\ ${ }^{4}$ 非会員ＪFE シビルエンジニアリングセンター（干230-8611＼cjkstart神奈川県横浜市鶴見区末広町 2-1）
}

\begin{abstract}
バラスト軌道の耐震性能を評価するため, これまでに小型模型や実物大模型を用いた振動台試験 を行い，バラスト軌道の道床横抵抗力に関する検討が行われてきた．本研究では，軌きょう模型や 曲線部模型を用いた小型模型傾斜試験や大型振動台試験により，バラスト軌道の道床横抵抗力を検 討した．その結果，準静的な慣性力あるいは加振力が作用する道床の横抵抗力は，常時あるいは地 震後の道床横抵抗力よりも小さい. また, 直線部・曲線部の道床形状の違いが道床横抵抗力に及ぼ 寸影響は小さいが，L2 地震動を想定した地震時および地震後の道床横抵抗力は，まくらぎ本数が 1 本で評価した場合と複数本からなる軌きょうで評価した場合で異なる傾向を示すことが明らかとな った.
\end{abstract}

Key Words : Ballasted track, Lateral resistance, Small-scale tilting test, Full-scale shaking table test, Seismic performancee

\section{1. はじめに}

日本は世界有数の地震国であり，地震に対する鉄道構 造物の安全性を高めることは重要な課題である.

1980年代においてバラスト軌道の而震に関する研究と

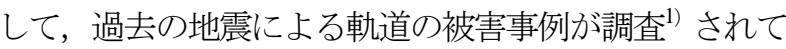
おり, 列車の走行安全性が損なわれた事例の中に, 構造 物や路盤に大きな変状が見られない場合でも，バラスト 軌道が大きく変形寸る場合があることが報告されている. バラスト軌道は，温度上昇に伴い，レールが長軸方向 一伸長しようとするのを拘束されることでレールに軸力 が生じる．この軸力によって軌道を横方向に座屈させよ うとする力が道床の横方向の抵抗力（以下，道床横抵抗 力）を上回ると，著大なレール水平変位（以下，座屈） が発生する. 特にロングレール区間では軸力が増加しや すく, 常時においても酷暑期には軌道の座屈が懸念され 2)，地震時にはさらに座屈の危険性が高まる恐れがある. しかし，地震によるバラスト軌道の変形メカニズムは十
分に解明されていない.これまでに行われたバラスト軌 道の而震に関する研究では，1980年代に東海地震に対す る検討の一環として, 実物大振動試験により, 地震後に おける道床横抵抗力の低下率と加振加速度の関係が検討 され，一定の成果が示された3)，4．

一方，1995年の兵庫県南部地震以降，鉄道における各 種構造物は地震に対応した設計法の整備が進められてい るが5)，バラスト軌道については，常時の設計法が定め られているものの6), 地震に対しては未整備である. 常 時において道床横抵抗力を評価する際には, 一般的に, まくらぎ1本を水平に載荷し, 水平変位 $2 \mathrm{~mm}$ 時における 水平荷重を最終道床横抵抗力としている77. これは，ま くらぎ1本を水平載荷した場合のまくらぎ水平変位 $2 \mathrm{~mm}$ 時における道床横抵抗力が，軌きょうの場合の最終道床 横抵抗力の70〜80\%程度の值となること，およびまくら ぎ1本の場合は, 軌きょう全体が移動する場合と比較して 道床横抵抗力が約 15～20\%程度高くなることから，まく らぎ1本の水平変位 $2 \mathrm{~mm}$ 時における道床横抵抗力は軌き 
よう全体が移動した場合の最終道床横抵抗力と概的等し

くなるためであるの, 7).

最近では，バラスト軌道の而震性能に関して行われた 研究において，まくらぎ1本の実物大模型を用いてL2地 震動を想定した大型振動台試験を行い，地震後の道床横 抵抗力が評価されてきた ${ }^{8)}$. しかし，地震中における検 討は行われておらず，また，まくらぎ本数が複数本から なる軌きょうの場合の道床横抵抗力の特性や直線部・曲 線部の道床横抵抗力の違いについても十分な検討が行わ れていない.

そこで，本研究では，小型模型を用いた傾斜試験およ び実物大模型を用いた大型振動台試験により，地震中に おける道床横抵抗力の特性を検討し，また，まくらぎ本 数が 1 本の場合と複数本の軌きょうの場合，さらに道床 形状が直線部と曲線部の場合について，バラスト軌道の 而震性能を評価することとした。

\section{2. 小型模型傾斜試験}

\section{(1) 試験概要}

地震中における軌きょうの道床横抵抗力を評価するた め，小型模型を用いた傾斜試験による道床横抵抗力試験 を行った. 図-1 に示寸ように，傾斜機構を有する試験土 槽を用いて，模型軌道に水平方向の慣性力を準静的に作 用させた。試験土槽表面には，コンクリートまくらぎと 同等の摩擦抵抗（摩擦係数 $0.6 〜 0.7 ）$ となるように，サ ンドペーパーを貼付した。

試験ケースを表-1 に示す．試験には標準軌（軌間 $1,435 \mathrm{~mm}$ ）を想定した $1 / 5$ 模型軌道を用いた。模型軌道
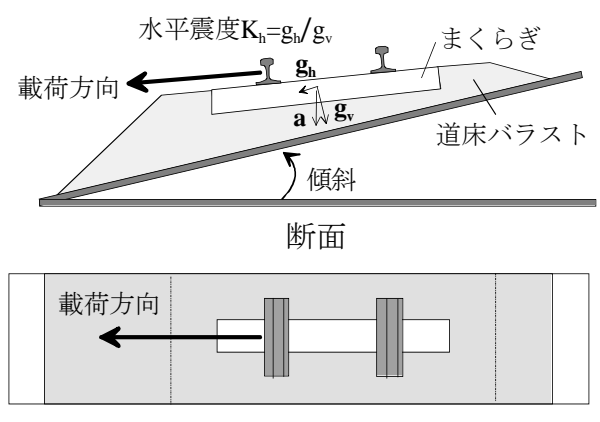

上面

図-1 傾斜試験概要（例：曲線部の道床形状）

表-1 試験ケース

\begin{tabular}{|c|c|c|c|}
\hline $\begin{array}{l}\text { 試験 } \\
\text { ケース }\end{array}$ & $\begin{array}{l}\text { 道床 } \\
\text { 形状 }\end{array}$ & $\begin{array}{c}\text { まくらぎ } \\
\text { 本数 } \\
\end{array}$ & 傾斜角度 \\
\hline 1 & \multirow{2}{*}{ 直線 } & 1 & \multirow{4}{*}{$\begin{array}{c}0 \text { 度 } \\
20 \text { 度 }\end{array}$} \\
\hline 2 & & 3 & \\
\hline 3 & \multirow{2}{*}{ 曲線 } & 1 & \\
\hline 4 & & 3 & \\
\hline
\end{tabular}
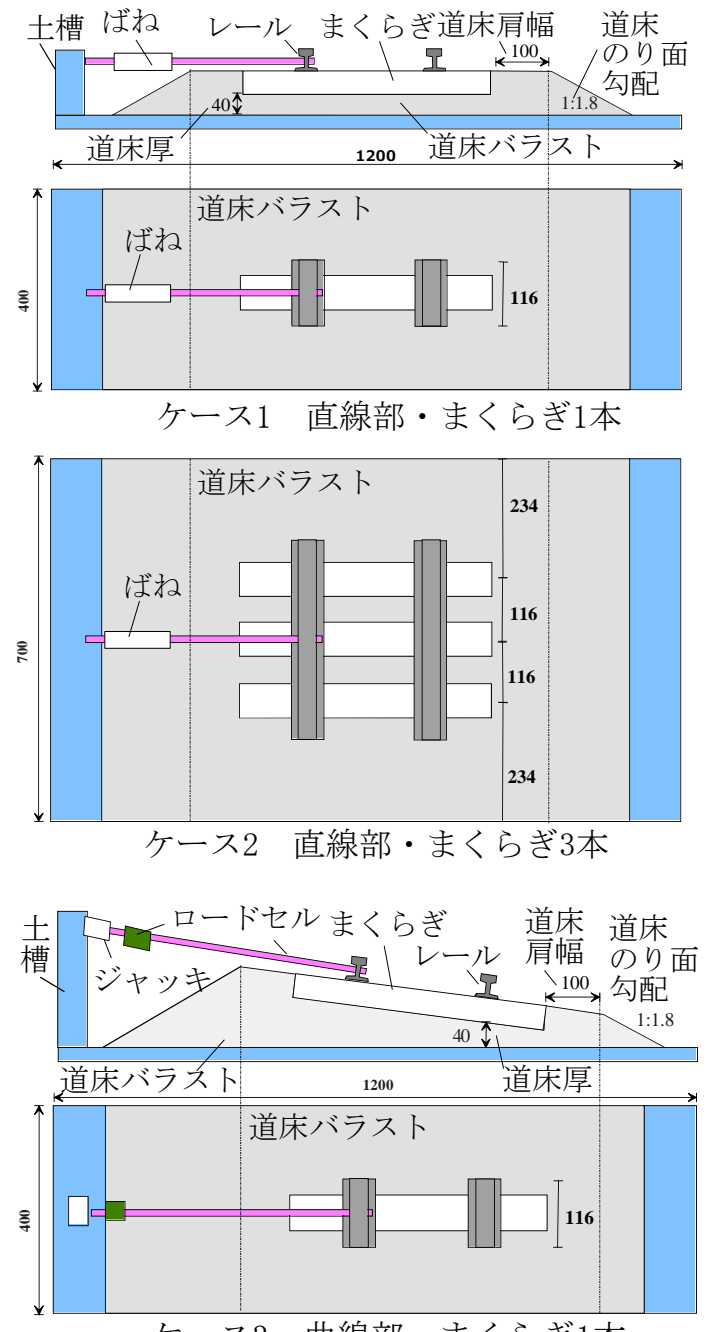

ケース 3 曲線部・まくらぎ1本

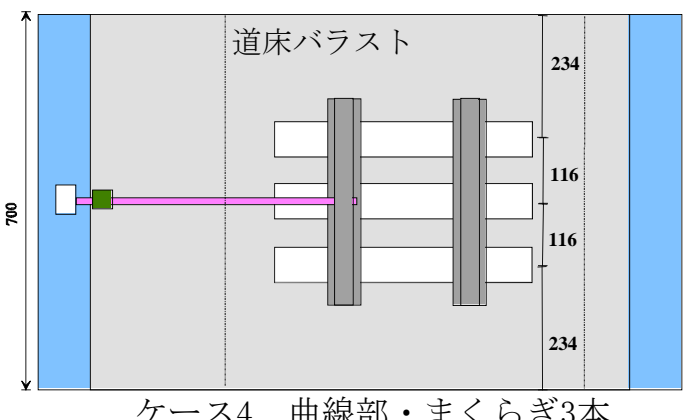

図-2 各試験ケースの道床形状

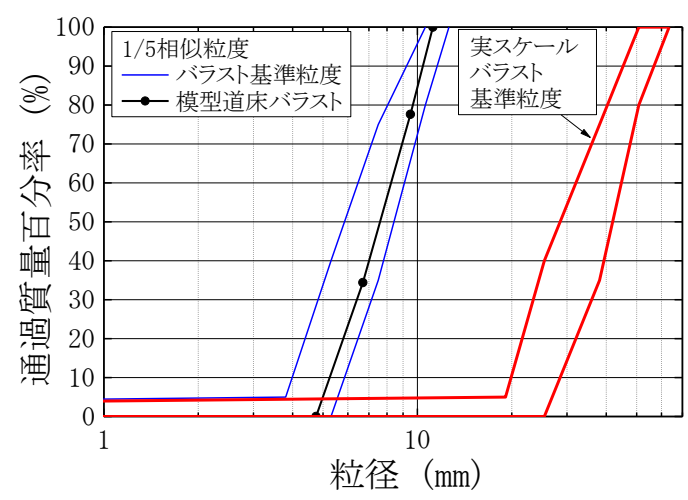

図-3 模型道床バラストの粒径加積曲線 


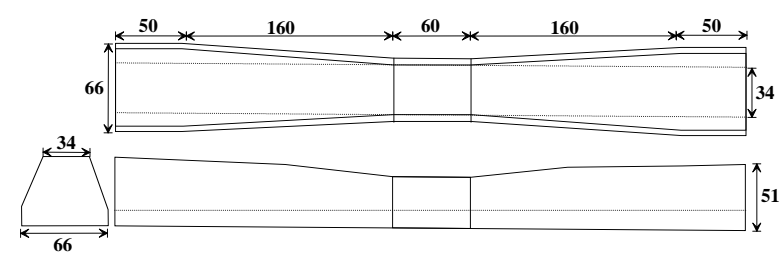

図-4３H まくらぎ模型（1/5 スケール）

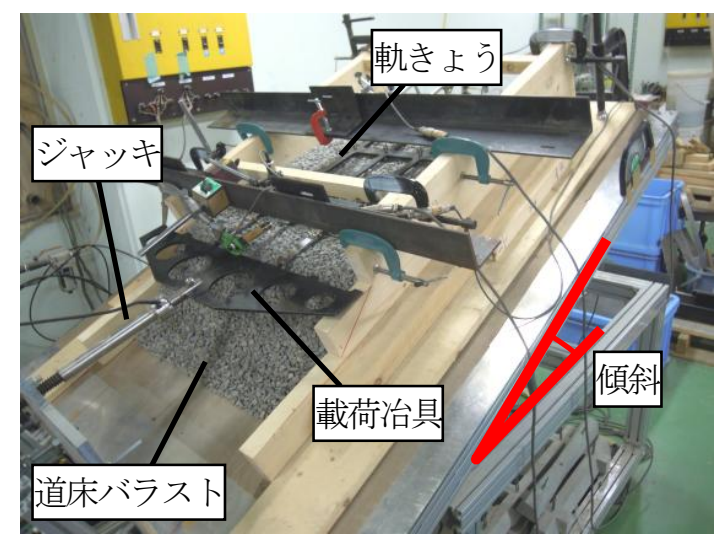

図-5 小型模型傾斜試験状況

の概要を図-2 に示す，模型軌道は，模型まくらぎ 1 本も しくは模型まくらぎ 3 本と模型道床バラストから構成さ れ，模型道床バラストには図-3 に示寸 $1 / 5$ 相似粒度の砕 石を用い，密度は，同じ石質の実物道床バラストの単位 容積質量 $1.6 \mathrm{t} / \mathrm{m}^{3}$ とした. 模型まくらぎは, コンクリート 製であり，3Hまくらぎと同形状とした（図-4)，道床形 状は, 道床肩幅 $100 \mathrm{~mm}$, 道床厚 $40 \mathrm{~mm}$ とし, 曲線部の場 合はカント $40 \mathrm{~mm}$ とした。傾斜角度は，0 度（常時）と 20 度（水平加速度 $357 \mathrm{gal}$ 相当）とした. 試験状況を図-5 に示寸.

載荷試験は，準静的な慣性力を加えたまま，まくらぎ 長手方向に載荷速度 $0.4 \mathrm{~mm} / \mathrm{min}$ (実スケール $2.0 \mathrm{~mm} / \mathrm{min}$ ) で水平載荷を行うものである. 載荷時には載荷荷重，ま くらぎ水平変位を測定した.

\section{(2) 準静的な慣性力を受ける道床の横抵抗力特性}

図-6および図-7に，まくらぎ本数 1 本および 3 本の小 型模型を用いた傾斜角度 0 度 (常時) および 20 度 (水平 加速度 $357 \mathrm{gal}$ 相当）におけるまくらぎ水平変位と道床横 抵抗力の関係を示寸。

それによると，直線部では，傾斜角度 0 度の場合，ま くらぎ 1 本の水平変位 $0.4 \mathrm{~mm}$ （実スケール $2 \mathrm{~mm}$ ）時にお ける道床横抵抗力が $0.080 \mathrm{kN}$ ，まくらぎ 3 本の軌きょう の最終道床横抵抗力が $0.067 \mathrm{kN}$ であった. なお，最終道 床横抵抗力とは, 水平変位 5 10mm の道床横抵抗力の 平均值である。水平加速度 $357 \mathrm{gal}$ 相当である 20 度の傾 斜を与えた条件において，まくらぎ 1 本の水平変位 $0.4 \mathrm{~mm}$ 時における道床横抵抗力が $0.035 \mathrm{kN}$ ，まくらぎ 3 本の軌きょうの最終道床横抵抗力が $0.041 \mathrm{kN}$ であった.

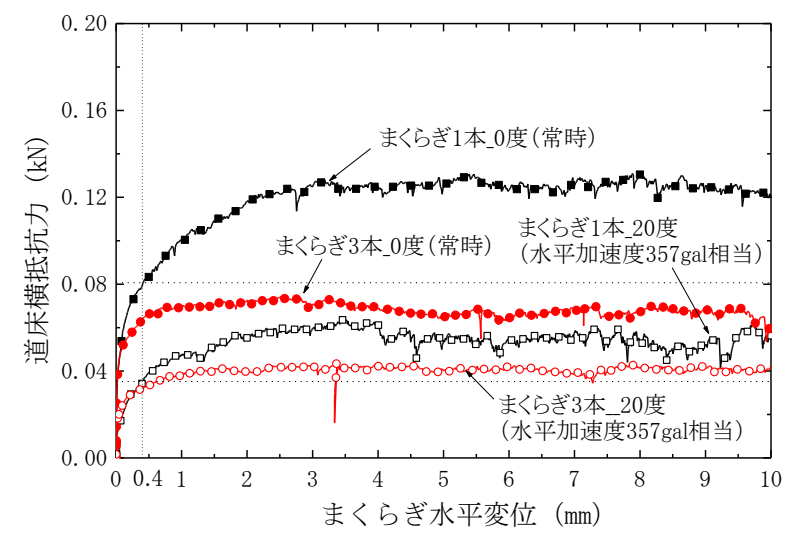

図-6 まくらぎ水平変位と道床横抵抗力の関係 (直線部)

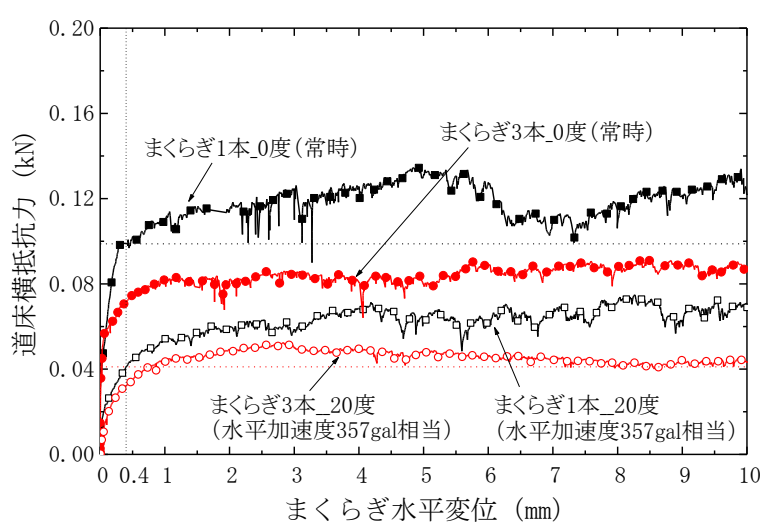

図-7 まくらぎ水平変位と道床横抵抗力の関係 (曲線部)

曲線部（実スケールでカント $200 \mathrm{~mm}$ 相当）では，常時 の場合, まくらぎ 1 本の水平変位 $0.4 \mathrm{~mm}$ 時における道床 横抵抗力が $0.099 \mathrm{kN}$ ，まくらぎ 3 本の軌きょうの最終道 床横抵抗力が $0.087 \mathrm{kN}$ であった。傾斜角度 20 度の場合, まくらぎ 1 本の水平変位 $0.4 \mathrm{~mm}$ 時における道床横抵抗力 が $0.041 \mathrm{kN}$ ，まくらぎ 3 本の軌きょうの最終道床横抵抗 力が $0.044 \mathrm{kN}$ であった.

傾斜角度 0 度（常時）では，道床形状によらず，まく らぎ 3 本の軌きょうの最終道床横抵抗力は，まくらぎ 1 本の水平変位 $0.4 \mathrm{~mm}$ 時よりも小さいが, 直線部より曲線 部の方が道床横抵抗力が大きい結果となった。 また, 傾 斜（水平加速度を作用させる）すると，道床形状によら ず, まくらぎ 3 本の軌きょうの最終道床横抵抗力の方が, まくらぎ 1 本の水平変位 $0.4 \mathrm{~mm}$ 時の道床横抵抗力よりも 大きい結果となった.

具体的には，傾斜による道床横抵抗力の低減率は，ま くらぎ 1 本の場合, 直線部で $56 \%$, 曲線部で $57 \%$ であっ たのに対し，まくらぎ 3 本の軌きょうの最終道床横抵抗 力は，直線部で 39\%，曲線部で 49\%であり，軌きょうの 場合の方が低下率が小さかった. まくらぎ複数本からな る軌きょうの場合，隣接まくらぎの影響により，各まく らぎ端部において道床肩部で負担する道床横抵抗力の影 
響範囲が重なり合い，一種の群杭効果によって道床肩部 で負担する抵抗力がまくらぎ 1 本での場合よりも低下寸 $3^{9}$. 傾斜機構により水平方向の慣性力を加えると, 道 床肩部のバラスト強度が低下し，もともと道床肩部の抵 抗力が小さいまくらぎ 3 本の軌きょうの方が道床横抵抗 力の低下の影響が小さくなるためであると考えられる.

\section{3. 大型振動台試験}

\section{(1) 試験概要}

小型模型傾斜試験を実施したのち，より実際の現象に 則した, 加振中および加振後の道床横抵抗力を評価する ため，大型振動台試験を行った，加振には，油圧サーボ 方式の加振装置を備えた大型振動台試験装置を用いた. 試験土槽は，X 軸 $7 \mathrm{~m} ， Y$ 軸 $5 \mathrm{~m}$ ，高さ $0.6 \mathrm{~m}$ の鉄製であ り，振動台テーブル上にボルトで剛結した．大型振動台 試験の状況を図-8 に示す. 加振中は常にロングレールが 軌道を座屈させようとする荷重に相当する引張り荷重を ばねにより軌道模型に作用させた。ばねは 80〜 $100 \mathrm{~mm}$ 程度のストロークに対して張力変化率が $15 \%$ 程度のも のを用いた。

実物大模型は，高架橋上における新幹線の標準的な断 面形状のバラスト軌道を想定し，道床厚 $200 \mathrm{~mm}$ ，道床肩

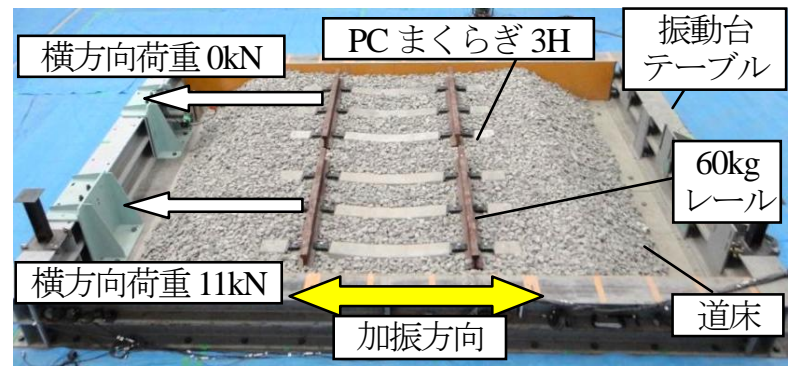

図-8大型振動台試験の状況（例 : ケース 3)
幅 500mm, 道床の法面の勾配 $1: 1.8$ とした. 本模型の 諸元を表-2 に示す．なお，まくらぎ 1 本あたりのレール 重量は，実軌道におけるまくらぎ間隔（レール $25 \mathrm{~m} /$ ま らぎ 43 本）より設定した. 実物大模型の概要を図-9に 示寸，道床形状は，小型模型傾斜試験と同様に，直線部 と曲線部の 2 種類であり, 曲線部の場合はカント $200 \mathrm{~mm}$ とした．模型延長は，まくらぎ 1 本の場合とまくらぎ 3 本の軌きょうの場合（道床形状が直線部の場合のみ）の 2 種類とした. 高架橋上の新幹線バラスト軌道を想定し, バラスト・路盤間の摩擦係数を考慮してセメントボード

表-2 実物大模型の諸元

\begin{tabular}{|c|c|}
\hline まくらぎ & PCまくらぎ3H \\
\hline レール & $60 \mathrm{~kg}$ \\
\hline まくらぎ間隔 & $581 \mathrm{~mm}$ \\
$(3$ 本模型の場合 $)$ \\
\hline 道床肩幅 & $500 \mathrm{~mm}$ \\
\hline 道床厚 & $200 \mathrm{~mm}$ \\
\hline
\end{tabular}

表-3 試験条件

\begin{tabular}{|c|c|c|c|c|c|c|}
\hline $\begin{array}{l}\text { 試験 } \\
\text { ケース }\end{array}$ & $\begin{array}{l}\text { 道床 } \\
\text { 形状 }\end{array}$ & $\begin{array}{c}\text { まくらぎ } \\
\text { 本数 }\end{array}$ & $\begin{array}{c}\text { まくらぎ } \\
\text { No. }\end{array}$ & $\begin{array}{c}\text { 引張り } \\
\text { 荷重 } \\
\end{array}$ & $\begin{array}{l}\text { 道床横抵 } \\
\text { 抗力試験 }\end{array}$ & 加振ステップ \\
\hline \multirow{4}{*}{ ケース 1} & \multirow{4}{*}{ 直線部 } & \multirow{4}{*}{ 1本 } & 1 & $2 \mathrm{kN}$ & - & \multirow{10}{*}{$\begin{array}{l}\text { (1) 正弦波 } 200 \mathrm{gal} \\
\text { (2)正弦波 } 400 \mathrm{gal} \\
\text { (3) 中越波 } 600 \mathrm{gal} \\
\text { (4) 中越波 } 700 \mathrm{gal} \\
\text { (5) 正弦波 } 600 \mathrm{gal} \\
\text { (6) 正弦波 } 700 \mathrm{gal} \\
\text { (7) 正弦波 } 800 \mathrm{gal}\end{array}$} \\
\hline & & & 2 & $4 \mathrm{kN}$ & - & \\
\hline & & & 3 & $6 \mathrm{kN}$ & 加振前 & \\
\hline & & & 4 & $0 \mathrm{kN}$ & 加振後 & \\
\hline \multirow{4}{*}{ ケース 2} & \multirow{4}{*}{ 曲線部 } & \multirow{4}{*}{ 1本 } & 1 & $2 \mathrm{kN}$ & - & \\
\hline & & & 2 & $4 \mathrm{kN}$ & - & \\
\hline & & & 3 & $6 \mathrm{kN}$ & 加振前 & \\
\hline & & & 4 & $0 \mathrm{kN}$ & 加振後 & \\
\hline \multirow{2}{*}{ ケース 3} & \multirow{2}{*}{ 直線部 } & \multirow{2}{*}{ 3本 } & 1 & $11 \mathrm{kN}$ & 加振前 & \\
\hline & & & 2 & $0 \mathrm{kN}$ & 加振後 & \\
\hline
\end{tabular}

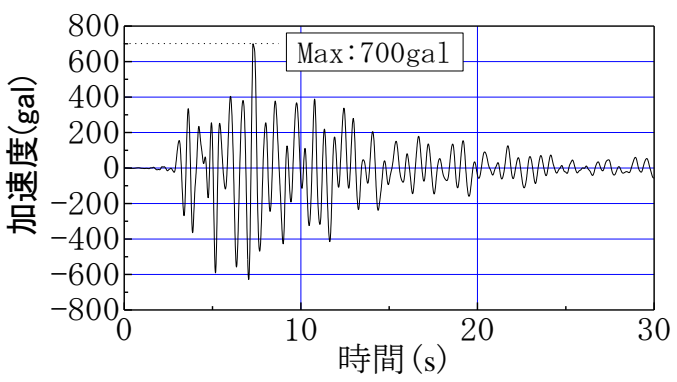

図-10 加振試験の地震波形（中越波）

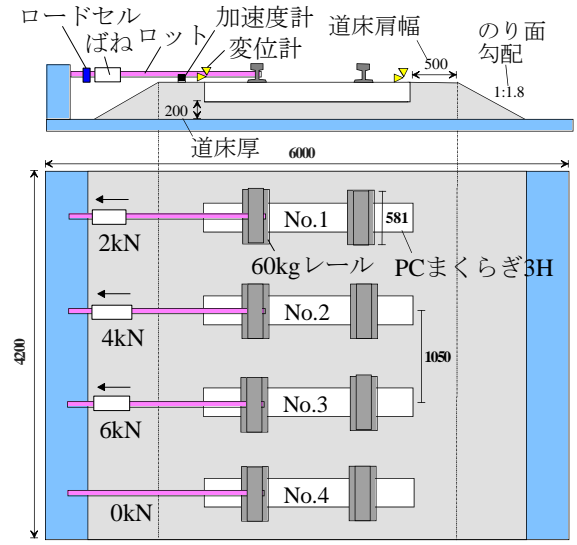

（a）ケース $1:$ ケくらき 1 本一直線部

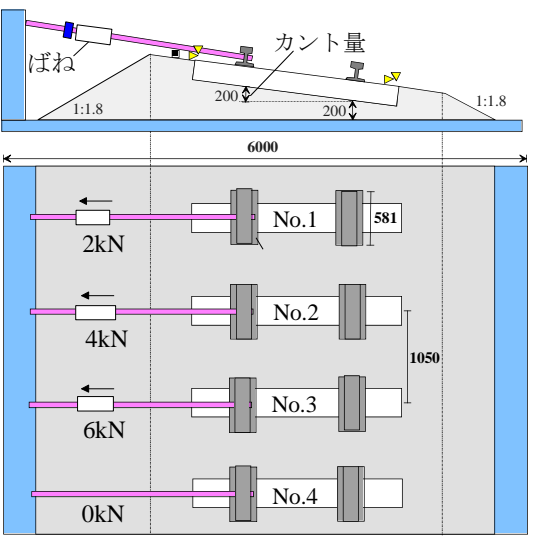

（b）ケース 2 : まくらぎ 1 本一曲線部 図-9 実物大模型の概要

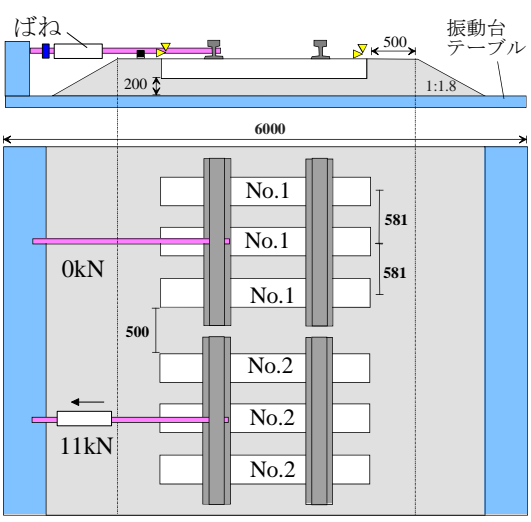

（c）ケース $3:$ ケくらぎ 3 本一直線部 
表-4引張り荷重とレール温度変化の関係

\begin{tabular}{|c|c|c|c|c|}
\hline \begin{tabular}{c|c|c|} 
レールの \\
温度変化
\end{tabular} & $29^{\circ} \mathrm{C}$ & $40^{\circ} \mathrm{C}$ & $42^{\circ} \mathrm{C}$ & $52^{\circ} \mathrm{C}$ \\
\hline $\begin{array}{c}\text { 引㖘 } \\
\text { 荷重 }\end{array}$ & $2 \mathrm{kN}$ & $\begin{array}{c}11 \mathrm{kN} / 3 \\
\text { 本 }\end{array}$ & $4 \mathrm{kN}$ & $6 \mathrm{kN}$ \\
\hline
\end{tabular}

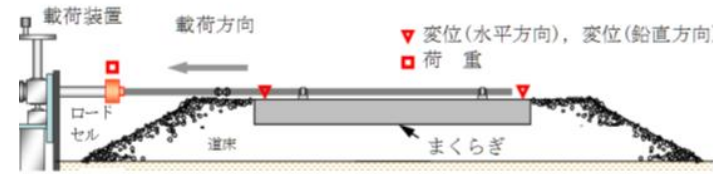

図-11 道床横抵抗力試験の概要

を振動台テーブル上に設置した．その上に，バラストを 投入し，道床密度 $1.6 \mathrm{t} / \mathrm{m}^{3}$ となるように振動バイブレータ 一を用いて締め固め, バラスト軌道を構築した。 まくら ぎ1本の場合は, まくらぎをレール長手方向に4本並べ, まくらぎ 3 本の場合はまくらぎ 3 本からなる軌きょうを レール長手方向に 2 つ並べて，振動台テーブル上に配置 した．実物大模型のまくらぎおよび軌きょうの配置間隔 は，隣接するまくらぎまたは軌きょうの影響が小さくな るように設定した.

加振試験および道床横抵抗力試験の試験条件を表-3に 示寸．加振波形は，正弦波（載荷周波数 $3 \mathrm{~Hz} ，$ 正弦波 10 波）および地震波であり，加振方向はレール直角水平方 向である，地震波は，新潟県中越地震における十日町高 架橋上面の応答波である ${ }^{10)}$ (図-10）（以下，「中越波」 とする). 加振中に作用させる引張り荷重は, 温度変化に よりロングレールが軌道を座屈させようとする荷重を想 定して，まくらぎ 1 本の場合が $0 \mathrm{kN}, 2 \mathrm{kN}, 4 \mathrm{kN} ， 6 \mathrm{kN}$ の 4 種類，まくらぎ 3 本の場合が $0 \mathrm{kN} ， 11 \mathrm{kN}$ （まくらぎ 1 本あたり $3.7 \mathrm{kN}$ 程度）の 2 種類とした。 なお，まくらぎ 3 本の場合の $11 \mathrm{kN}$ につては, まくらぎ 1 本あたり $4 \mathrm{kN}$ の引張り荷重となるように $12 \mathrm{kN}$ の引張り荷重を設定す るつもりであったが, ばねのストローク不足により $11 \mathrm{kN}$ とした. 表-4に引張り荷重とレール温度変化の関係を示 す.引張り荷重はエネルギー法を用いて算出した ${ }^{11)}$. 加 振試験の計測項目は，まくらぎ両端部の水平変位，ばね の引張り荷重，および振動台テーブル・引張り荷重の作 用側の道床肩部の応答水平加速度である.

道床横抵抗力試験は，加振試験前および正弦波 $800 \mathrm{gal}$ 加振後の軌道模型に対して，図-11 に示寸載荷装置を用 いて, 載荷速度 $2 \mathrm{~mm} / \mathrm{min}$ でまくらぎ長手方向に載荷を行 った，道床横抵抗力試験の計測項目は，まくらぎ両端部 の水平変位および引張り荷重である.

\section{（2）加振中の道床横抵抗力特性}

\section{a) 道床形状の影響}

図-12 および図-13に, 直線部および曲線部の道床形状

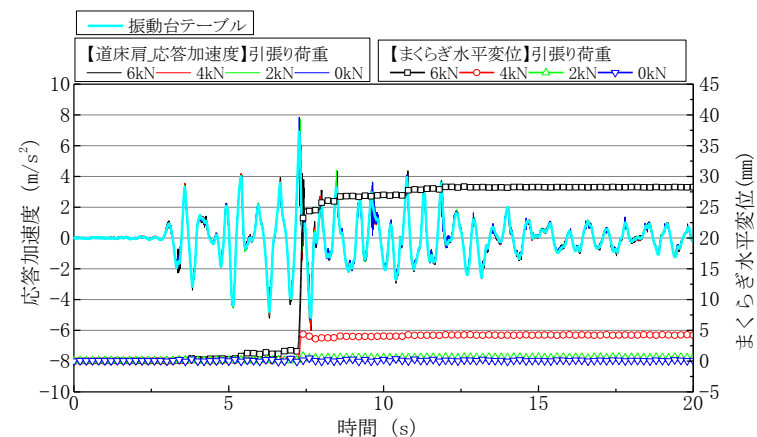

中越波 700gal

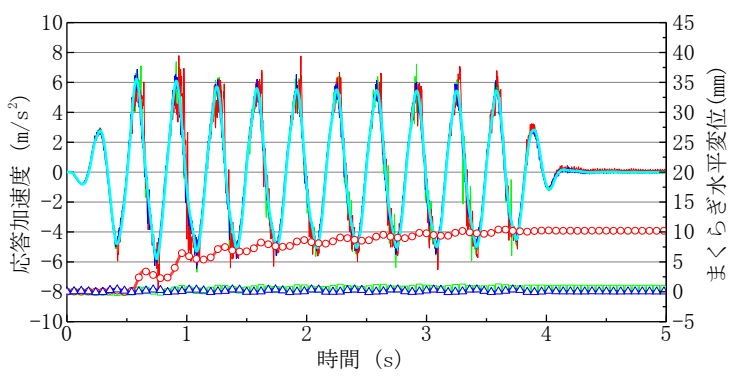

正弦波 600gal

図-12 まくらぎ変位波形(まくらぎ1本・直線部)

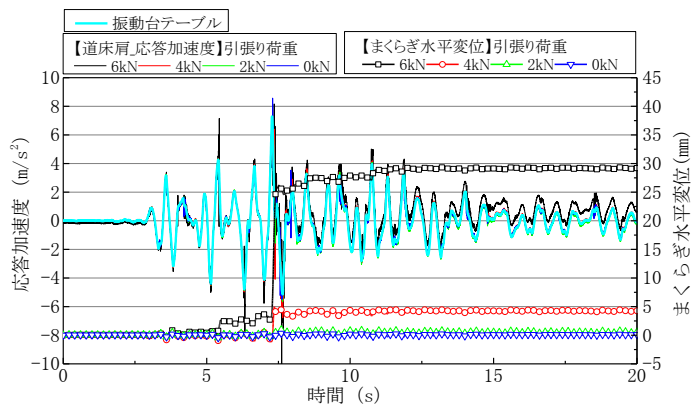

中越波 700gal

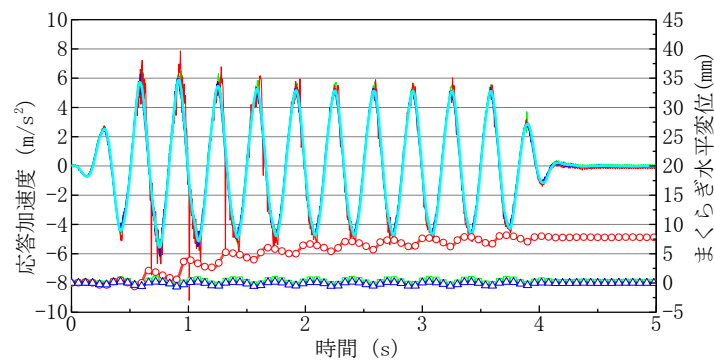

正弦波 600gal

図-13 まくらぎ変位波形(まくらぎ1本・曲線部)

における道床肩部の応答加速度波形，振動台テーブルの 応答加速度波形およびまくらぎ变位波形を示す. 各加振 ステップにおいて，道床肩部の応答加速度波形およびま くらぎ変位波形は，道床形状によらず概衩同様の傾向を 示しており，道床形状の違いが加振中におけるバラスト 軌道の変形特性に及ぼす影響は小さいと考えられる。

次に, 中越波 700gal 加振では, 道床形状によらず, 最 大加速度が生じた際にまくらぎ水平変位が増大して残留 変位が発生するが，その前後では残留変位がほとんど生 じていないことがわかる．これは，道床肩部の応答加速 
度波形が振動台テーブルと概ね同様の応答特性を示して いることから，慣性力により一時的に道床肩部の道床横 抵抗力が限界値に達したものの，すぐに回復したためと 考えられる. また，正弦波 $600 \mathrm{gal}$ 加振では，道床形状に よらず, 引張り荷重 $4 \mathrm{kN}$ においてまくらぎ変位が増加し ているが, 3〜4 波目以降は残留変位の増加速度が低下し ていることがわかる.これは，最大加速度作用時におい て道床肩部の応答加速度に高周波成分が発生しているこ とから，加振により道床肩部の剛性が低下し，道床横抵 抗力が低下したことで残留変位が増加したものと考えら れるが，詳細については，今後，分析を進める．また， 2 〜3 波目で最大加速度が 600gal 程度に達した後に加振加 速度が 500gal 程度に減少したため, 加振途中で残留変位 の増加速度が低下したものと考えられる。つまり，道床 バラストの応答加速度が 600gal 程度に達すると, 道床肩 部におけるバラストの剛性が低下寸ることが考えられる. 直線部および曲線部の道床形状における引張り荷重 $4 \mathrm{kN}$ 載荷の場合の加振中のまくらぎ変位波形を図-14 お よび図-15 に示す，直線部および曲線部とも，各加振ス テップのまくらぎ変位波形が，概ね同様の傾向を示して いることがわかる，中越波の場合，最大加速度が作用し た際にまくらぎ残留変位が生じ，道床形状が直線部およ び曲線部のどちらの場合においても $700 \mathrm{gal}$ 加振で $4 \mathrm{~mm}$ 程度であった．正弦波 $700 \mathrm{gal}$ の場合は，加振波数が増加 するにつれてまくらぎ変位が急増した。

引張り荷重と各加振ステップのまくらぎ残留変位の関 係を図-16および図-17 に示す. 直線部および曲線部とも 各加振ステップにおけるまくらぎ残留変位は概初同等で あると考えられる．また，引張り荷重が増加するほど, 各加振ステップのまくらぎ残留変位が増大していること がわかる．引張り荷重 $4 \mathrm{kN}$ は，まくらぎ変位 $2 \mathrm{~mm}$ 時に おける正弦波 $800 \mathrm{gal}$ 加振後の道床横抵抗力の 8 割程度で あるが, 加振中は正弦波 700gal でもまくらぎ水平変位が 急増した. また，引張り荷重 $2 \mathrm{kN}$ は，まくらぎ変位 $2 \mathrm{~mm}$ 時における正弦波 $800 \mathrm{gal}$ 加振後の道床横抵抗力の $1 / 3$ 程 度であるが, 加振中は直線部の正弦波 $800 \mathrm{gal}$ で $51 \mathrm{~mm}$ の 残留変位が生じた。型模型傾斜試験では準静的な慣性 力を受けると道床横抵抗力が減少した. 同様に大型振動 台試験の加振中においても道床横抵抗力は著しく低下し, 引張り荷重が加振後の道床横抵抗力より小さくても大き な残留変位が生じることがわかった。

\section{b) まくらぎ本数の影響}

図-18 に，直線部についてまくらぎ 1 本とまくらぎ 3 本の場合におけるまくらぎ変位および道床肩部の応答加 速度波形を示寸。

中越波 700gal 加振では, 最大加速度が生じた際にまく

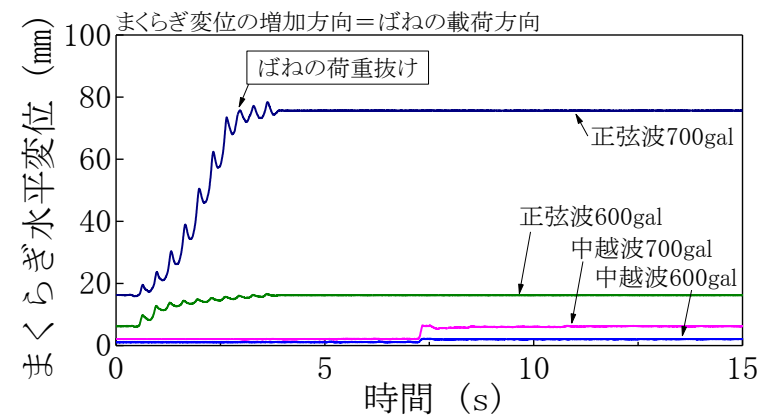

図-14 まくらぎ変位波形(まくらぎ 1 本・直線部 : $4 \mathrm{kN})$

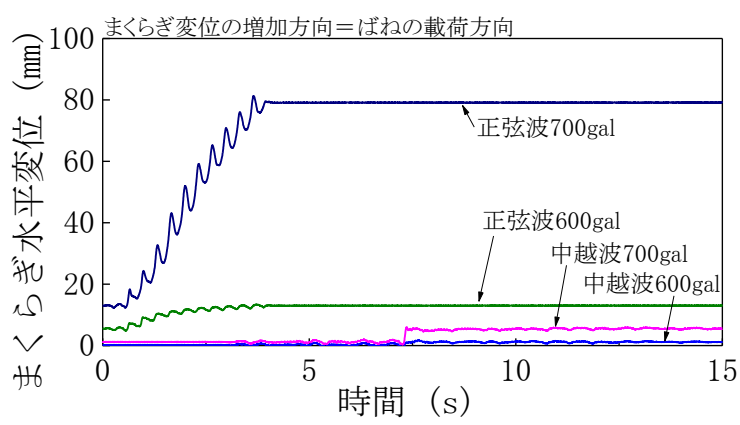

図-15 まくらぎ変位波形(まくらぎ 1 本・曲線部 : 4kN)

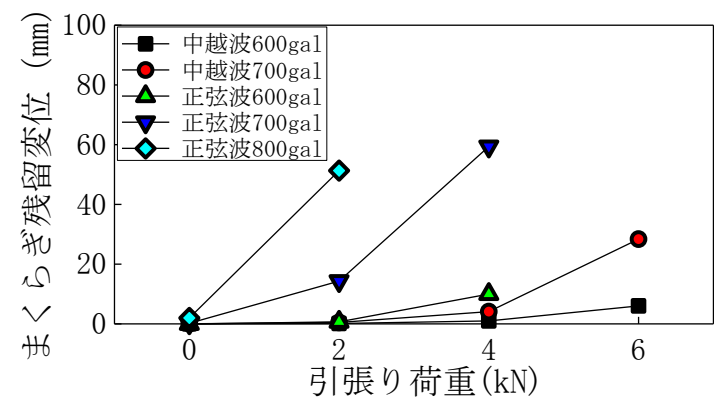

図-16 まくらぎ残留変位（まくらぎ 1 本・直線部 $)$

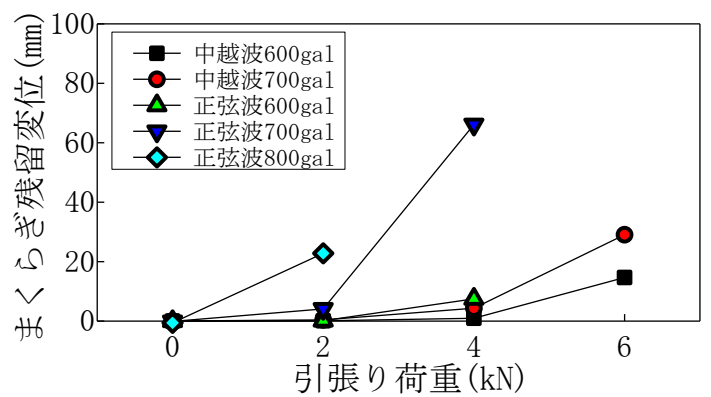

図-17 まくらぎ残留変位（まくらぎ 1 本・曲線部）

らぎ水平変位が増大して残留変位が発生しており，まく らぎ 1 本の場合と同様の傾向を示していることがわかる. しかし，まくらぎ 3 本の場合では， 1 本あたり $3.7 \mathrm{kN}$ 程 度の引張り荷重であるのに対して，まくらぎ 1 本模型の 引張り荷重 $6 \mathrm{kN}$ の場合と同程度の残留変位が発生した. これは，小型模型傾斜試験て観察されたように，群杭効 果によりまくらぎ 1 本あたりの道床横抵抗力が低下した ためと考えられる。 


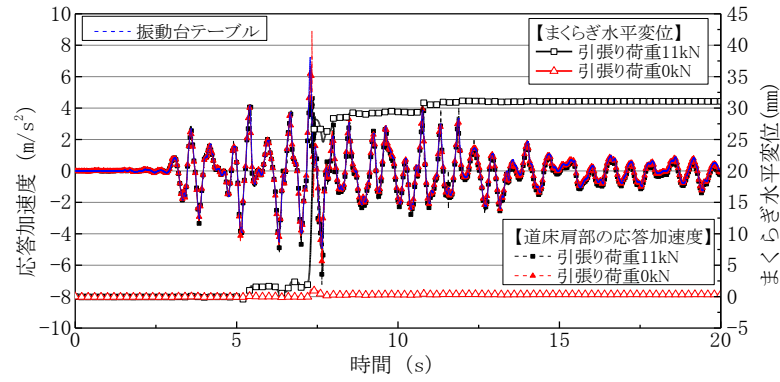

中越波 700 gal

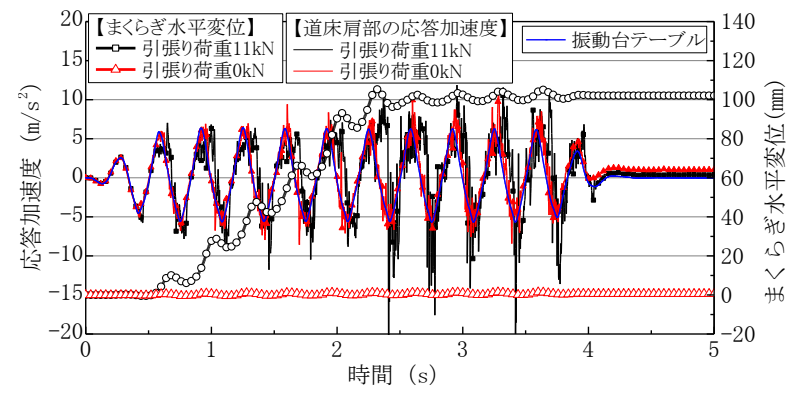

正弦波 600gal

図-18 まくらぎ変位および道床肩部の 応答加速度波形(まくらぎ 3 本・直線部)

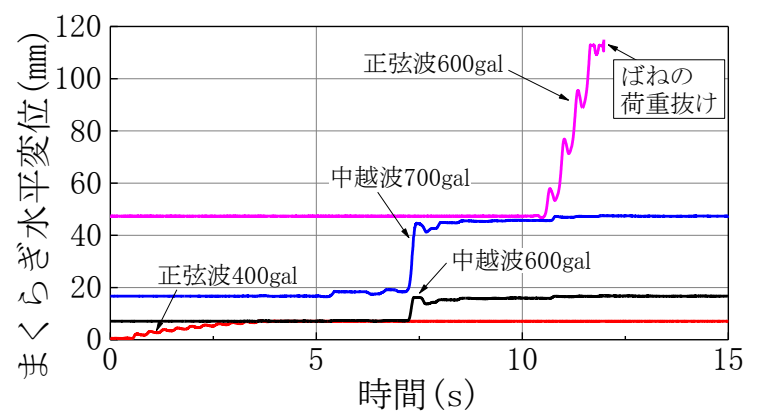

図-19 まくらぎ変位波形(まくらぎ 3 本・直線部)

正弦波 600gal 加振では，まくらぎ 1 本の場合よりも大 きなまくらぎ残留変位が発生しており，道床肩部の応答 加速度波形に顕著な高周波成分が発生していることがわ かる. 高周波成分については, 加振により道床肩部の剛 性が低下し，道床横抵抗力が低下したことで発生したも のと推察される. つまり，まくらぎ本数が増えることに よる群杭効果と, 加振による道床肩部の岡性低下により, 加振中に道床横抵抗力が著しく低下し，まくらぎ残留変 位が増大したものと考えられる。

図-19 にまくらぎ 3 本の場合の加振中におけるまくら ぎ変位波形を示す．中越波の場合は最大加速度が作用し た際にまくらぎ変位が大きく発生し，正弦波加振では波 数とともにまくらぎ変位が増加する傾向であった．これ は，まくらぎ 1 本の場合と同様の傾向にあることがわか る. また，引張り荷重 $11 \mathrm{kN} （ 3.7 \mathrm{kN} /$ 本）は，まくらぎ 3 本の場合における正弦波 $800 \mathrm{gal}$ 加振後の道床横抵抗力/

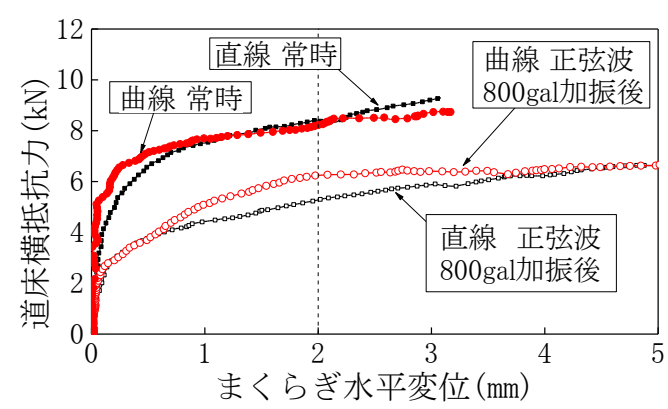

図-20 まくらぎ水平変位と道床横抵抗力の関係 (道床形状の影響)

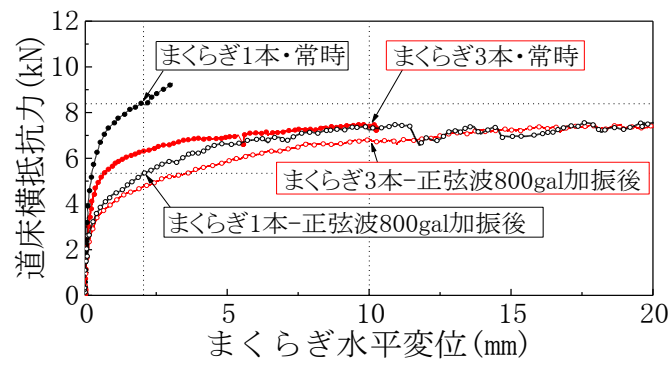

図-21 まくらぎ水平変位と道床横抵抗力の関係 （まくらぎ本数の影響，直線部）

本 $(6.8 \mathrm{kN})$ の 6 割程度であるが，正弦波 600gal 加振中 にまくらぎ変位が急増していることがわかる。つまり， 加振中において道床横抵抗力は低下し, 加振後の道床横 抵抗力より小さい引張り荷重でも大きな残留変位が生じ ることがわかった。

\section{(3) 加振後の道床横抵抗力特性}

\section{a) 道床形状の影響}

常時および正弦波 $800 \mathrm{gal}$ 加振後の道床横抵抗力とまく らぎ変位の関係を図-20に示す，常時の道床横抵抗力は, 直線部および曲線部とも概祆同様の傾向を示しており， まくらぎ変位 $2 \mathrm{~mm}$ 時で, 直線部が $8.4 \mathrm{kN}$, 曲線部が $8.2 \mathrm{kN}$ であった．正弦波 $800 \mathrm{gal}$ 加振後は, 直線部および曲線部 ともに道床横抵抗力が低下し, まくらぎ変位 $2 \mathrm{~mm}$ 時で, 直線部が $5.3 \mathrm{kN}$, 曲線部が $6.2 \mathrm{kN}$ であった. 加振後の道 床横抵抗力の低下率は直線部の方が大きく $37 \%$ 程度で あり, 曲線部は $24 \%$ 程度であった. しかし, まくらぎ変 位が $4 \mathrm{~mm}$ 以降は直線部と曲線部で同程度の道床横抵抗 力を示した.

\section{b) まくらぎ本数の影響}

直線部形状における加振前および正弦波 800gal 加振後 の道床横抵抗力とまくらぎ変位の関係を図-21 に示寸. なお，まくらぎ 3 本の荷重は，まくらぎ 1 本あたりに換 算している. 加振前の道床横抵抗力は，まくらぎ 1 本の 場合が $2 \mathrm{~mm}$ で $8.4 \mathrm{kN}$ ，まくらぎ 3 本の場合が $10 \mathrm{~mm}$ で $7.4 \mathrm{kN}$ であり, まくらぎ 3 本の場合の道床横抵抗力の方 
がやや小さい值となった.

正弦波 $800 \mathrm{gal}$ 加振後の道床横抵抗力は，まくらぎ 1 本 の場合が $2 \mathrm{~mm}$ で $5.3 \mathrm{kN}$ ，まくらぎ 3 本の場合が $10 \mathrm{~mm}$ で $6.8 \mathrm{kN}$ であった. 加振後の道床横抵抗力の低下率は，ま くらぎ 1 本の場合の方が大きく $37 \%$ 程度であり, まくら ぎ 3 本の場合は $9 \%$ 程度であった。 これは，小型模型試 験と同様に，群杭効果により，もともとまくらぎ端部の 寄与分が小さいためにまくらぎ 3 本の方がまくらぎ端部 周辺の強度低下の影響が小さくなり，加振後の道床横抵 抗力の減少量が小さくなったためと考えられる.

\section{4. 結論}

小型模型試験および実物大模型を用いた大型振動台試 験より，以下の知見を得た。

(1) 準静的な慣性力あるいは加振力が作用する道床の横 抵抗力は常時あるいは地震後の道床横抵抗力より小 さい.

（2）小型模型試験および実物大模型試験より，道床形状 が曲線部の場合の方が道床横抵抗力がやや大きいも のの，直線部および曲線部の道床形状の違いが，加 振中および加振後の道床横抵抗力に与える影響は小 さいと考えられる.

(3) 小型模型試験および実物大模型試験より，常時では まくらぎ 1 本の場合のまくらぎ変位 $2 \mathrm{~mm}$ 時よりも, まくらぎ 3 本の場合のまくらぎ変位 $10 \mathrm{~mm}$ 時の方が 道床横抵抗力はやや小さくなったが，加振後ではま くらぎ 3 本の場合のまくらぎ変位 $10 \mathrm{~mm}$ 時の方が道 床横抵抗力は大きくなることがわかった。

(4) 軌きようによる群杭効果により，加振中の道床横抵 抗力は軌きょうの方がまくらぎ端部周辺の岡性低下
の影響が小さく，加振後の道床横抵抗力の減少量が 小さくなることがわかった.

(5) まくらぎ本数によらず，加振中に道床横抵抗力は低 下し，ロングレールの座屈荷重を想定した引張り荷 重が加振後の道床横抵抗力より小さくても，加振中 に大きな残留変位が生じることがわかった。

\section{参考文献}

1) 三浦重，切敷啓介：地震による列車および軌道の被害 に関する文献調查，鉄道技術研究所速報，No.82-45， 1982

2）沼田実:ロングレールの座屈強さ, 鉄道技術研究報告, No.721， 1970

3）佐藤吉彦，小林悟，永田正巳：地震時における道床横 抵抗力，鉄道技術研究報告，No.675，1969.4

4) 佐藤吉彦, 高谷博文, 鈴木俊一：軌道の地震時におけ る座屈安定性の検討，鉄道技術研究報告，No.1334， 1987.1

5）（財）鉄道総合技術研究所編 : 鉄道構造物等設計標準・ 同解説 土構造物，2007.1.

6)（公財）鉄道総合技術研究所編 : 鉄道構造物等設計標 準・同解説 軌道構造，2012.1

7) 佐藤吉彦, 宮井徹 : 各種有道床まくらぎ軌道の道床横 抵抗力とその特性, 鉄道技術研究所速報, No.76-150, 1976.11

8) 中村貴久, 関根悦夫, 白江雄介 : 大型振動台試験によ るバラスト軌道の耐震性能評価, 鉄道総研報告, Vol.24, No.12, 2010.12

9）小池陽平，早野公敏，中村貴久，桃谷尚嗣 : まくらぎ の形状と本数がバラスト軌道の道床横抵抗力に及ぼ 寸影響, 第 48 回地盤工学研究発表会, 2013.7

10）航空・鉄道事故調査委員会 : 鉄道事故調査報告書 I 東日 本旅客鉄道株式会社上越新幹線浦佐駅～長岡駅間 列車脱 線事故，2007.11.30

11) 三浦重, 柳川秀明 : 急曲線へのロングレールの適用, 鉄道 総研報告，Vol.6, No.1, 1992.1

\title{
CHARACTERISTICS OF LATERAL RESISTANCE OF BALLASTED TRACKS UNDER SEISMIC CONDITIONS
}

\section{Takahisa NAKAMURA, Yoshitsugu MOMOYA, Kimitoshi HAYANO and Ryuta OGAWA}

\begin{abstract}
To evaluate charateristies of ballasted tracks under seicmic conditions, small-scale tilting tests and full-scale shaking table tests were conducted. The results showed that lateral resistances under seismic conditions were significantly lower those before or after seismic conditions. It was also revealed that lateral resistance of canted track was little different from that of non-canted track. However, significant difference was observed between the lateral resistance obtained from single sleeper conditions and that from track-panel conditions.
\end{abstract}

